but after only 40 or 50 years wo find that there were complaints in respect of the carrying capacity of the grazings, and only now, after 150 years, science is awakening to a condition of affairs long recognized by practical flockmasters. The condition of semi-starvation and disease into which we have again plunged our hill flocks is only now being properly appreciated; it has even been quoted in a Government report, and we, at this late date, would seek means to rectify it.

The second matter concerns the dairy cow which has been bred to produce a truly enormous quantity of milk. The present standards of production could never have been reached by the breeder without the aid of the nutritionist. So nicely are dietaries balanced today that what might appear a slight alteration in the dairy regimen may produce a considerable reduction in milk secretion. The modern milch cow has been likened to a machine working under high pressure and consequent strain, and the same is true of the laying hen. Are we not in this matter going too far the other way? I mean, are we not here exploiting the art of feeding and the science of nutrition so fully that we are adversely affecting the stamina of the stock? I think we are.

\title{
REFERENCES
}

Orr, J. B. (1931). Trans. Highl. agric. Soc. Scot. (5th Series), 43, 44.

Ure, D. (1794). General View of the Agriculture of the County of Roxburgh. London.

\section{The Wintering of Hill Sheep}

\section{Mr. Martin Jones (North of Scotland College of Agriculture, Aberdeen)}

Dr. Russell Greig has dealt with the nutrition of animals over the whole of Scotland on both good and bad land. I propose to confine my remarks to the nutrition of animals in the poorest part of Scotland, the Highlands, where there is about 10 million acres of rough grazing. As Dr. Greig mentioned, in the past there was a time when there was good grazing on the hills, but for the last 100 years the grazing in the Highlands has been such that animals kept on the hills the whole time have not be en able to maintain condition. This was largely because the plants on the rough grazings were grazed by the same number of stock all the year through. Any plants that survived were those which remained green and succulent for merely a few weeks in the summer and for the rest of the year were dry, hard and woody. They were good enough for mature sheep and possibly for mature cattle, but their fibrous condition made them unsuitable for hoggs during their first winter. Thus the hoggs were sent to winter in the lowlands where they ran over the fields of arable grass.

This was a bad system since sometimes no such winter pasturage could be procured. When prices were good, the lowland farmer himself went in for breeding sheep. It was difficult enough, however, for him to maintain his own ewe stock and he had no room for hoggs from the hills. When prices slumped, the Highland farmer had no money to pay for wintering so the sheep had to suffer. During the war years the same thing happened but for a different reason; there was not much lowland pasture for hill sheep because of the ploughing campaign, and we came to a point when the upland farmer had to look for winter keep at home. 
An attempt was made to improve pasture on rough grazing by using fertilizers, but it has not been a great success. One can hardly expect benefits from manure when it is applied to plants which are not naturally green in winter. Latterly we attempted to establish plants which grow quickly and are succulent for most of the year, such plants as are used in lowland pastures. We found that it was not difficult to establish these plants on the hills through the agency of the plough, provided the land was properly limed and manured, but to get them established meant an expenditure of from $£ 12$ to $£ 14$ an acre.

The justification of such an expense depended on how long the better plants would persist. Should those grasses disappear in three years' time and it become necessary to re-establish them again, the process. would be uneconomic. We therefore had to try to make the grasses persist longer. We knew we could make them persist for at least 12 years. provided they were grazed hard in summer and given a rest in winter. But sheep require the grasses in winter; so the problem was how to make use of them at that critical time and yet make them persist. We believed we could get the use of the grasses during each winter from October to. March provided that, for the rest of the year, the grazing was controlled in the interest of the grasses rather than in the interest of the animals. That meant fencing so as to control the grazing. Further we had to study the different phases through which the grasses passed before we could decide how to manage the pasture during the summer months.

The natural procedure for all grass plants is to produce seed during the summer, between May and August. They have to build up stems to ensure the seeds being spread properly, and to build up that fibrous structure means expending energy. It is possible to prevent the adverse effect of seed production on the vigour of the plant by grazing fairly closely between May and August so that none of the tillers are allowed to extend far enough to form seed heads.

The type of animal used for this summer grazing has a bearing on the eventual character of the sward; as implements to control the grass in summer cattle are preferable to sheep. Whereas cattle have to be content with removing the more erect tillers, sheep are able to select the young side shoots and leave the erect tillers to carry on developing their stems. and seed heads.

In the spring, however, up to the middle of May, seed production will not have commenced and at that time only leaves will be put up. As the leaf is its factory, the less grazing the plant gets at that time the better it will thrive.

Again, after the middle of August, the plants do not put up seed stalks but revert to fortifying themselves with more leaf growth, and when frost comes they close down the leaves and the nutriment goes back into the base of the plant, ready to come up the following spring to feed the developing buds. Hence after the middle of August the more protection given to the plant, the stronger it becomes and the better it will persist.

So the best treatment for the plant consists in protection from grazing during April and the first half of May, close grazing from the middle of May until the middle of August, followed by a rest from mid-August to mid-October.

voL. 4, 1946] 
We were fortunate to find a farmer who was interested in trying a system based on these principles. In 1938 he decided to fence 30 acres of hill land carrying heather or heather and bracken. He then ploughed the land that was ploughable within this fence, i.e., about 15 acres of it, the remainder consisting of rocks and boulders. The ploughed portion was left fallow till the following spring. In April 1939 he applied lime and at the beginning of May sowed the seeds. In 6 weeks' time Highland cattle were turned in. These grazed the grass for 2 months and then the grass was given a complete rest for 7 weeks. Hoggs which previously would have gone to the lowlands, were put in and allowed to pull at the grass during the winter from October to mid-April. The pasture was then cleared of stock for a whole month. During that month the early grasses regained some of their strength. The cattle were introduced at the middle of May 1940 and they kept the grass well down until the middle of August. This was followed by seven weeks' rest before the winter grazing with hoggs started again.

The scheme has now been going for 6 years and so far there is very little deterioration in the grass. Since the cattle kept down the grasses during the summer, the clovers have done exceedingly well and the sward on this hill land seems to be getting richer each year though no manure was given after the first year.

The progress of the stock has also been studied. The young sheep wintered in this way are growing well and their subsequent progress on the open hill was followed to see what the next generation would be like. No adverse effect was found in the second generation. The cows too, though used as implements, paid their way handsomely by rearing excellent calves each summer. Thus at the end of six years there was no deterioration in the quality of the stock and no appreciable deterioration in the sward, and there is no reason to expect that we cannot go on for a further six years. There are thus good chances that we can use reseeded pastures on the hill to carry young sheep over the winter and yet maintain the sward in good order for many years, provided those pastures are properly grazed with cattle during the summer months. It is not possible to plough everywhere on the hills, and it is not economic to manure the present fibrous plants. Areas which can be reasonably tackled should therefore be selected for direct reseeding.

If utilization of the land in the Highlands could be established on such a system, it would be of great benefit to the stock and also to the shepherd. When a hill farmer has to get wintering for lambs in the lowlands he often has to send a shepherd with them. Shepherds dislike being away from their families throughout the winter. The method discourages new recruits.

With regard to the returns apart from improvement of the hill, the 15 acres ploughed up are wintering anything from 100 to 120 hoggs, i.e., they are worth about $\mathfrak{i} 4$ per acre for winter keep. In the first 3 years the winter keep alone paid for all the expense of ploughing, manuring and seeding. The purchase of cattle meant a big outlay, but the outlay brought a good return because calves are a useful source of money in autumn.

As regards the best type of cattle to use on the hill after reseeding, a fully grown cow of the beef type is an ideal animal for maintaining the 
quality of the sward. She will bear a calf, give it sufficient milk, and put on weight during the summer. She will, however, give no more milk than is sufficient for a single calf. Any nourishment obtained over and above that requirement will be stored in the body to tide her over the winter. Above all we have here a method whereby a suitable type of cow, one that will produce a good feeding bullock, can rear that calf economically whilst, by combining cattle rearing with sheep rearing, the rough pastures on the hills can be utilized without much expenditure on labour.

This experiment has justified itself and we are going on with it, extending it, and trying out improvements. I am not prepared to say whether it is the best possible system, but it is one method by which a full stock can be maintained on the vast hill areas.

This trial represents a real improvement in the health of hill stocks. During the years before the war so many lambs kept at home in an undernourished condition were in a stunted condition in spring; when they were sent back to the hill, disease took a heavy toll.

Two other experiments were made on the wintering of hoggs. In each case a field was set aside in summer and the grass converted into silage which was fed back to the same ground during the winter. The hoggs did well on grass silage, and when it was stopped each spring they went back to the habit of roaming the hills as usual, contrary to the opinion frequently expressed.

\section{Discussion}

Mr. M. Griffith (Welsh Plant Breeding Station, Aberystwyth), opener: To discuss Dr. Russell Greig's paper would take too long. I have enjoyed listening to it. We know too little of the history of agriculture.

As a Welsh member of the Hill Sheep Farming Committee, I think there should be much more interesting interchange of ideas between Scotland and Wales. They have so much in common. Conditions in Wales differ in that we find among farmers and shepherds no prejudice against sending hoggs to the lowlands, but then Welsh hill pastures are more grassy on the whole than those of Scotland. There is room for research on a large scale on these problems.

There is a strong feeling in Wales that pedigree sheep breeders in "improving" sheep have not given enough attention to the question of hardiness. This is important for mountain breeds, especially when the mature stock are wintered at high elevations.

With reference to the improvement of hill pastures, work has been going on in Wales for 11 or 12 years. Some of the pastures laid down about 12 years ago are still going strongly, though some of the better grasses have diminished to a certain extent, their place being taken by Agrostis, but we have been able to keep up the percentage of wild white clover to a very marked degree.

To maintain the sward, cattle must be used for summer grazing. Young cattle bred in the lowlands have been agisted on the hills, and they have made satisfactory progress. Pastures grazed in April and May recover after a short rest. For maximum winter keep they require a longer autumn rest, say from the beginning of August. The stockcarrying capacity of most of the hills which we have tackled, ranging voL. 4,1946 ] 